\title{
Pengaruh Employee Stock Ownership Program, Total Asset Turnover dan Leverage Terhadap Return On Asset Pada Perusahaan yang Terdaftar di Bursa Efek Indonesia
}

\author{
Rosalina Yessyca \\ Program Studi Akuntansi Syariah, Fakultas Ekonomi dan Bisnis Islam, IAIN Madura, Indonesia \\ Email: Ryessyca25@gmail.com \\ Wadhan \\ Program Studi Akuntansi Syariah, Fakultas Ekonomi dan Bisnis Islam, IAIN Madura, Indonesia \\ Email:Wadhan.751@gmail.com
}

\begin{abstract}
:
This research uses a quantitative approach with associative type and uses multiple linear regression analysis method. The data source is obtained from secondary data in the form of annual financial reports obtained through the official website of the Indonesia Stock Exchange with a sample of 10 companies and using four reporting periods. The results of this study indicate that the results of calculations and statistical tests with linear regression method using SPSS produce an $\mathrm{R}$ square value of 0.504 or $50.4 \%$, this indicates that simultaneously the independent variables (ESOP, TATO, Leverage) have an effect of $50.4 \%$ on dependent variable (ROA) and the rest is influenced by other factors not examined. And based on partial testing, each independent variable (ESOP, TATO, Leverage) has a significant effect on the dependent variable (ROA) seen from the t-count value $(3.321 ; 3.874 ; 2.813)$ which is greater than the table (2.030).
\end{abstract}

Keywords: ESOP, Total Asset Turnover, Leverage, Return On Asset

\begin{abstract}
Abstrak:
Penelitian ini menggunakan pendekatan kuantitatif dengan jenis asosiatif dan menggunakan metode analisis regresi linier berganda. Sumber datanya diperoleh dari data sekunder berupa laporan keuangan tahunan yang di dapatkan melalui website resmi Bursa Efek Indonesia dengan jumlah sampel perusahaan sebanyak 10 perusahaan dan menggunakan empat periode pelaporan. Hasil penelitian ini menunjukkan bahwa dari hasil perhitungan dan uji statistik dengan metode regresi linier menggunakan SPSS menghasilkan nilai $\mathrm{R}$ square sebesar 0,504 atau $50,4 \%$ hal ini menunjukkan bahwa secara simultan variabel independennya (ESOP,TATO,Leverage) berpengaruh sebesar $50,4 \%$ terhadap variabel dependennya (ROA)dan sisanya dipengaruhi oleh faktor lain yang tidak diteliti. Dan berdasarkan pengujian secara parsial masing-masing variabel independen (ESOP,TATO,Leverage) mempunyai pengaruh yang signifikan terhadap variabel dependennya (ROA) dilihat dari nilai t hitung $(3,321 ; 3,874 ; 2,813)$ yang dihasilkan lebih besar dari t tabelnya $(2,030)$.
\end{abstract}

Kata Kunci: ESOP, Total Asset Turnover, Leverage, Return On Asset 


\section{PENDAHULUAN}

Dalam keberlangsungan kegiatan operasional perusahaan terdapat banyak elemen penting dan pendukung dalam menjalankan suatu perusahaan, salah satunya adalah karyawan. Konflik kepentingan dapat terjadi antara pemegang saham dengan manajer dan karyawan, antara pemegang saham mayoritas dan pemegang saham minoritas dalam suatu perusahaan. Adanya perbedaan kepentingan ini, baik secara langsung atau tidak langsung bisa mempengaruhi kinerja perusahaan. Terdapat beberapa cara untuk mengurangi perbedaan kepentingan antara para pemilik dan manajemen perusahaan salah satunya ialah dengan menerapkan Employee Stock Ownership Program. ${ }^{1}$ Employee Stock Ownership Plan ialah program kepemilikan karyawan atas saham perusahaan dimana hal ini diharapkan dapat meningkatkan rasa memiliki (sense of belonging) sehingga mendukung peningkatan kinerja perusahaan. ${ }^{2}$

Laba dan tingkat profitabilitas yang tinggi merupakan salah satu tujuan utama sebuah perusahaan didirikan, dimana semua kegiatan perusahaan yang dilakukan baik yang bersifat operasional maupun non operasional yang merupakan sarana untuk mencapai tujuan tersebut. Laba tentunya dipengaruhi oleh beberapa aspek diantaranya ialah total aktiva, aktiva lancar, hutang lancar, dan penjualan. ${ }^{3}$ Untuk dapat mengetahui implementasi dari penentuan tingkat perputaran total aktiva (Total Assets Turnover) terhadap kemampuan perusahaannya dalam memperoleh laba, kita harus memperhatikan pengelolaan seluruh aktiva yang baik. Dimana pengelolaan aktiva secara efektif dan efisien sangatlah penting bagi perusahaan karena dapat meningkatkan tingkat Profitabilitas.

Leverage ialah penggunaan biaya tetap atas asset ataupun beban tetap atas dana untuk meningkatkan hasil (return) pemilik perusahaannya. Terdapat tiga jenis leverage, diantaranya ialah operating leverage dimana leverage jenis ini timbul akibat penggunaan aktiva (asset) yang menimbulkan biaya tetap. Yang kedua financial leverage dimana leverage ini timbul akibat penggunaan dana dengan hutang, dan yang terakhir total leverage dimana leverage ini merupakan gabungan dari operating leverage dan financial leverage. ${ }^{4}$

Profitabilias sebuah perusahaan dapat diukur menggunakan Return on Assets (ROA), yakni berarti tingkat pengembalian investasi dalam aktiva serta diukur dengan Return on Equity (ROE) yang merupakan tingkat pengembalian modal sendiri. ${ }^{5}$ Dalam penelitian kali ini peneliti memfokuskan mengukur profitabilitas perusahaan menggunakan sisi Return on Assets.

\footnotetext{
${ }^{1}$ Ria Ans Kurniati dan Muhammad Saifi(2018), Pengaruh Employee Stock Ownership Program dan Leverage terhadap kinerja keuangan (Studi pada Perusahaan Sektor Perbankan yang Terdaftar Di Bursa Efek Indonesia Tahun 2014-2016), Jurnal Administrasi Bisnis Vol. 62 No. 2 September 2018 administrasibisnis.studentjournal.ub.ac.id.hlm.151

${ }^{2}$ Herdinata, C. (2012). Reaksi Pasar Terhadap Pengumuman Employee Stock Ownership Program. Jurnal Keuangan dan Perbankan, Vol.16, hlm.77-85.

${ }^{3}$ M Firza A dan Ade Gunawan(2018), Pengaruh Current Ratio dan Total Assets Turnover Terhadap Return On Assets pada Perusahaan Plastik dan Kemasan. Jurnal Riset Akuntansi Vol. 17, No. 2.

${ }^{4}$ Endah Dewi Purnamasari(2017), Analisis Pengaruh Laverage terhadap Profitabilitas Perusahaan yang Termasuk LQ45 Periode Agustus 2015- Januari 2016 di Bursa efek Indonesia. Jurnal Ilmiah Ekonomi Global Masa Kini Vol 8 No 01 ISSN PRINT : 2089-6018.

${ }^{5}$ Yulita M. Gunde dkk(2017), analisis pengaruh leverage terhadap profitabilitas pada perusahaan manufaktur sub industri food and baverages yang terdaftar di BEI(periode 2012-2015), Jurnal EMBA Vol.5 No.3 September 2017, Hal.4185-4194 ISSN 2303-1174.
} 
Dalam penelitian kali ini terdapat beberapa rumusan masalah diantaranya adalah bagaimana pengaruh Employee Stock Ownership Program , Total Asset Turnover dan Leverage secara simultan terhadap Return On Asset pada perusahaan yang terdaftar di BEI. Serta bagaimana pengaruh Employee Stock Ownership Program , Total Asset Turnover dan Leverage secara parsial (masing-masing) terhadap Return On Asset pada perusahaan yang terdaftar di BEI.

Penelitian ini mempunyai tujuan untuk menjawab rumusan masalah yang terdapat di atas yang menanyakan pengaruh Employee Stock Ownership Program , Total Asset Turnover dan Leverage baik secara simultan maupun parsial terhadap Return On Asset pada perusahaan yang terdaftar di BEI sehingga hasil dari penelitian ini dapat memberikan manfaat bagi perusahaan yang membutuhkan.

\section{Employee Stock Ownership Program(ESOP)}

Employee Stock Ownership Program merupakan salah satu bentuk kompensasi yang diberikan kepada karyawan untuk menghargai kinerja jangka panjang perusahaan. Dalam sebuah perusahaan tidak semua karyawan berhak mendapatkan ESOP ini , hanya beberapa karyawan yang dapat memenuhi syarat dari perusahaan yang mendapatkannnya. Semisal karyawan yang dapat memenuhi target kinerja perusahaan yang telah diberikan. ${ }^{6}$

Employee Stock Ownership Program merupakan suatu program kepemilikan saham oleh karyawan perusahaan yang diharapkan dapat meningkatkan sense belonging yang dapat mendukung peningkatan kinerja perusahaan sehingga program ini memberikan pengaruh positif pada investor yang ditunjukkan melalui peningkatan harga pasar saham. ${ }^{7}$

\section{Total Asset Turnover( TATO)}

Total Assets Turnover merupakan rasio antara penjualan dengan total aktiva yang mengukur efesiensi penggunaan aktiva secara keseluruhan. Apabila rasio rendah itu merupakan indikasi bahwa perusahaan tidak beroperasi pada volume yang memadai bagi kapasitas investasinya. Total Asset Turnover secara sistematis dapat dirumuskan sebagai berikut : 8

Total Assets Turnover $=\underline{\text { Penjualan }}$

\section{Total aktiva}

\section{Leverage}

Leverage adalah penggunaan asset dan sumber dana (source of funds) oleh perusahaan yang memiliki biaya tetap (beban tetap) dengan maksud agar meningkatkan keuntungan potensil pemegang saham. Leverage adalah suatu tingkat kemampuan perushaan dalam menggunakan aktiva dan atau dana yang mempunyai beban tetap (hutang dan atau

\footnotetext{
6 Muhamad Yusril Arsyad(2018), Analisis Penerapan Employee Stock Ownership Program Terhadap Kinerja Perusahaan yang Terdaftar di Bursa Efek Indonesia,Dspace Universitas Islam Indonesia No. 14.

${ }^{7}$ Nur Afni Yunita (2018), Pengaruh Employee Stock Ownership Program (ESOP) Terhadap Profitabilitas Perusahaan Yang terdaftar di Bursa Efek Indonesia, Jurnal Visioner \& Strategis, Volume 7, Nomor 1, Maret 2018 ISSN: 2338-2864 p. 23-30

${ }^{8}$ Nur Anita Chandra Putry dan Teguh Erawati(2013), Pengaruh Current Ratio, Total Assets Turnover dan Net Profit Margin Terhadap Return On Assets. Jurnal Akuntansi Vol 1 No 2 Desember, hlm.23 
saham istimewa) salam rangka mewujudkan tujuan perusahaan untuk memaksimisasi kekayaan pemilik perusahaan. ${ }^{9}$

dalam penelitian kali ini mengukur leverage dengan menggunakan Debt to Equity Ratio (DER) dimana Debt to Equity Ratio merupakan rasio yang digunakan untuk menilai utang dengan ekuitas. Rasio ini dicari dengan cara membandingkan antara seluruh utang, termasuk utang lancar dengan seluruh ekuitas. ${ }^{10}$

$$
\text { DER }=\frac{\text { Total Hutang }}{\text { Ekuitas }}
$$

\section{Return On Asset (ROA)}

Return On Asset ialah rasio keuntungan bersih pajak yang juga merupakan suatu ukuran untuk menilai seberapa besar tingkat pembayaran kembali dari aset yang dimiliki oleh perusahaan. Semakin tinggi nilai ROA maka menunjukan semakin efisien perusahaan tertera dapat mengatur kekayaan yang dipunyai (manajemen aset). Begitu juga sebaliknya jika nilai ROA rendah sehingga manajemen aset perusahaan tertera dikatakan kurang efisien. ${ }^{11}$ ROA di hitung dengan menggunakan rumus berikut:

$$
\mathrm{ROA}=\frac{\text { Laba Bersih }}{\text { Total Aset }}
$$

\section{METODE PENELITIAN}

Penelitian ini menggunakan pendekatan kuantitatif dengan jenis penelitian asosiatif yang meneliti hubungan antara dua variabel atau lebih dan dengan menggunakan analisis regresi yang berguna untuk mengukur kekuatan hubungan antara satu variabel dengan variabel lainnya dan menunjukkan arah hubungan antara variabel dependen dengan variabel independen. Metode analisis yang dilakukan pada penelitian ini adalah metode analisis dengan menggunakan analisis regresi linear berganda. Sumber data yang digunakan dalam penelitian ini adalah data sekunder yang berupa laporan keuangan. Dimana laporan keuangan tersebut di dapat dari laporan keuangan go public perusahaan yang menerapkan Employee Stock Ownership Program di Bursa Efek Indonesia (BEI) melalui www.idx.co.id.

Jumlah perusahaan yang digunakan sebagai sampel adalah 10 perusahaan dan periode yang digunakan adalah 4 periode yaitu tahun 2016-2019. Adapun perusahaan yang di maksud adalah sebagai berikut:

\footnotetext{
${ }^{9}$ Yulita M. Gunde dkk(2017), analisis pengaruh leverage terhadap profitabilitas pada perusahaan manufaktur sub industri food and baverages yang terdaftar di BEI(periode 2012-2015), Jurnal EMBA Vol.5 No.3 September 2017, Hal.4185-4194 ISSN 2303-1174.

${ }^{10}$ Endah Dewi Purnamasari(2017), Analisis Pengaruh Laverage terhadap Profitabilitas Perusahaan yang Termasuk LQ45 Periode Agustus 2015- Januari 2016 di Bursa efek Indonesia. Jurnal Ilmiah Ekonomi Global Masa Kini Vol 8 No 01 ISSN PRINT : 2089-6018.

${ }^{11}$ Riccy Nurly Trisna,dkk(2018), Pengaruh Penerapan Employee Stock Ownership Plan (ESOP) pada Kinerja Perusahaan dan Imlikasinya pada Return Saham, E-Jurnal Akuntansi Universitas Udayana Vol.22.2. Februari (2018): 831-855 ISSN: 2302-8556
} 
Tabel 1

Sampel Penelitian (Perusahaan yang menerapkan Employee Stock Ownership Program dan menerbitkan laporan keuangan lengkap periode 2016-2019)

\begin{tabular}{cccc}
\hline NO & Kode Saham & Nama Perusahaan & Keterangan(Industri) \\
\hline 1. & AALI & PT. Astra Agro Lestari Tbk. & Agruculture \\
2. & AKRA & PT. AKR. Corporindo Tbk & Chemical \\
3. & APEX & Apexindo Pratama Duta Tbk & Mining \\
4. & ASGR & PT. Astra Graphia Tbk. & Electric \\
5. & AUTO & PT. Astra Otoparts Tbk. & Automotive \\
6. & IATA & PT. Indonesia Air Transport Tbk. & Transport \\
7. & MIDL & PT. Metrodata Electronics Tbk. & Electric \\
8. & PGAS & Perusahaan Gas Negara (Pesero) & Mining \\
9. & SCMA & PT. Surya Citra Media Tbk. & Others \\
10. & UNTR & United Tractors Tbk & Automotive \\
\hline
\end{tabular}

Sumber: Bursa Efek Indonesia

\section{HASIL DAN PEMBAHASAN}

Pada penelitian kali ini penulis menggunakan analisis regresi linier berganda. Akan tetapi sebelum melakukan analisis regresi linier berganda perlu dilakukan uji asumsi klasik terlebih dahulu sebagai langkah awal penelitian, uji asumsi klasik meliputi uji normalitas, multikolinieritas, heteoskedastisitas dan autokorelasi.

\section{Uji Asumsi Klasik Normalitas}

Dalam penelitian kali ini data yang digunakan berdistribusi normal, ditunjukkan dengan gambar yang dihasilkan dari Histogram Probability Plot sebagai berikut: 
Gambar 1

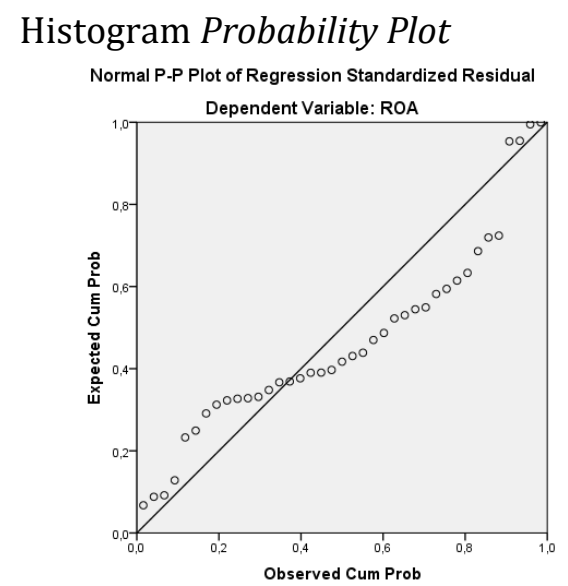

Sumber: Output SPSS 20 (Laporan Keuangan Publikasi, diolah)

\section{Multikolinieritas}

Dalam sebuah penelitian, multikolinieritas terjadi apabila antara variabel bebas (independen) memiliki korelasi yang tinggi. Untuk mendeteksi adanya multikolinieritas dalam model regresi dapat dilakukan dengan melihat nilai tolerance dan Variance Inflation Factor (VIF) pada output SPSSnya. Apabila nilai tolerancenya $>0,10$ dan nilai VIF $<10$, maka dapat dipastikan bahwa antar variabel bebas dalam model regresi tersebut tidak terjadi multikolinieritas. Namun sebaliknya, apabila nilai tolerancenya $<0,10$ dan nilai VIF $>10$, maka dapat disimpulkan bahwa antar variabel bebas dalam model regresi yang digunakan terjadi multikolinieritas. Dalam penelitian kali ini hasil uji multikolinieritas ditunjukkan berdasarkan hasil uji SPSS sebagai berikut:

Tabel 2

Hasil Uji Multikolinieritas

\begin{tabular}{|c|c|c|c|c|c|c|c|c|}
\hline \multirow{3}{*}{\multicolumn{2}{|c|}{ Model }} & \multicolumn{4}{|c|}{ Coefficients $^{a}$} & \multirow{3}{*}{ Sig. } & \multirow{2}{*}{\multicolumn{2}{|c|}{$\begin{array}{l}\text { Collinearity } \\
\text { Statistics }\end{array}$}} \\
\hline & & \multicolumn{2}{|c|}{$\begin{array}{l}\text { Unstandardized } \\
\text { Coefficients }\end{array}$} & \multirow{2}{*}{$\begin{array}{c}\text { Standardize } \\
\mathrm{d} \\
\text { Coefficients } \\
\text { Beta }\end{array}$} & \multirow[t]{2}{*}{$\mathrm{t}$} & & & \\
\hline & & B & Std. Error & & & & $\begin{array}{c}\text { Toleranc } \\
\mathrm{e}\end{array}$ & VIF \\
\hline & $\begin{array}{l}\text { (Constan } \\
\text { t) }\end{array}$ & $-1,810$ & 1,089 & & $-1,661$ & 106 & & \\
\hline 1 & ESOP & $\begin{array}{r}2,872 \mathrm{E}- \\
010\end{array}$ & ,000 & ,404 & 3,321 & ,002 & ,955 & 1,047 \\
\hline & TATO & ,067 & ,017 & ,487 & 3,974 & ,000 & ,943 & 1,061 \\
\hline & Leverage & ,004 & ,002 & 341 & 2,813 & ,008 & ,965 & 1,037 \\
\hline
\end{tabular}

a. Dependent Variable: ROA

Sumber: Output SPSS 20

Dapat dilihat bahwa pada masing-masing variabel independen nilai tolerancenya > 0,10 dan nilai VIF $<10$. Yaitu pada variabel ESOP nilai tolerancenya sebesar 0,955 dan nilai VIFnya sebesar 1,047, pada variabel TATO nilai tolerancenya sebesar 0,943 dan nilai VIFnya 
sebesar 1,061, sedangkan pada variabel Leverage nilai tolerancenya sebesar 0,965 dan nilai VIFnya sebesar 1,037. Dari nilai tersebut maka dapat ditarik kesimpulan bahwa tidak terjadi multikolinieritas pada variabel-variabel independen dalam model regresi ini.

\section{Heteroskedastisitas}

Dalam penelitian ini tidak terdeteksi adanya heteroskedastisitas yang ditunjukkan dengan hasil uji SPSS, dimana dalam gambar tersebut tidak menunjukkan pola yang teratur seperti yang biasanya terjadi ketika heteroskedastisitas terdeteksi. Gambar yang dimaksud adalah sebagai berikut:

Gambar 2

Uji Grafik Plot SRESID by ZPRED Scatterplot

Scatterplot

Dependent Variable: ROA

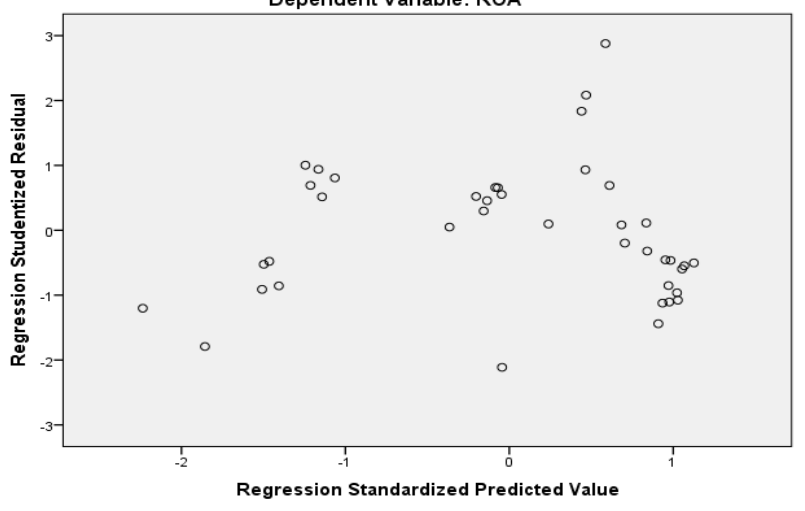

Sumber: Output SPSS 20 (Laporan keuangan publikasi, diolah)

\section{Autokorelasi}

Uji autokorelasi bisa dilakukan dengan uji Durbin-Watson (DW) yakni dengan membandingkan antara DW hitung dengan DW tabel dengan derajat kepercayaan sebesar $5 \%$. Dalam penelitian ini sempat terjadiauto korelasi yang di tunjukkan dengan hasil SPSS sebagai berikut:

Tabel 3

Uji Autokorelasi - Durbin Watson

Model Summary

\begin{tabular}{|c|c|c|c|c|c|}
\hline Model & $\mathrm{R}$ & R Square & $\begin{array}{l}\text { Adjusted R } \\
\text { Square }\end{array}$ & $\begin{array}{l}\text { Std. Error of } \\
\text { the Estimate }\end{array}$ & $\begin{array}{l}\text { Durbin- } \\
\text { Watson }\end{array}$ \\
\hline 1 &, $671^{a}$ & , 450 & ,404 & 7,811660 & ,612 \\
\hline
\end{tabular}

a. Predictors: (Constant), Leverage, TATO, ESOP

b. Dependent Variable: ROA

Sumber: Output SPSS 20 (Laporan keuangan Publikasi, diolah)

Pada tabel di atas dapat dilihat bahwa nilai $\mathrm{DW}=0,612$ dengan $\mathrm{K}=3$ dan $\mathrm{N}($ banyaknya sampel $)=40$ dengan signifikansi 0,05 . Untuk mencari nilai dU maka harus dilihat dari tabel Durbin Watson, untuk $\mathrm{K}=3$ dan $\mathrm{N}=40$ maka nilai $\mathrm{du}=1,659$. 
Untuk bebas dari autokorelasi maka dU $<$ DW $<4-\mathrm{dU}$, sementara pada model regresi ini nilai $\mathrm{dU}>\mathrm{Dw}<4-\mathrm{dU}(1,659>0,612<2,341)$ yang artinya ada indikasi terjadinya autokorelasi.

Untuk mengatasi hal tersebut, penulis menggunakan metode Cochrane Ocrutt untuk mengatasi adanya autokorelasi. Metode ini digunakan untuk menaikkan nilai DW pada tabel Model Summary model regresi linier pada suatu penelitian. Metode Cochrane Ocrutt dilakukan dengan menghitung nilai koefisien autokorelasi menggunakan nilai error pada model regresi. 12

Berikut adalah tabel baru setelah dilakukan perbaikan dengan menggunakan metode Cochrane Ocrutt.

Tabel 4

Autokorelasi - Durbin Watson (CO)

Model Summary

\begin{tabular}{|c|c|c|c|c|}
\hline Model & $\mathrm{R}$ & R Square & $\begin{array}{l}\text { Adjusted R } \\
\text { Square }\end{array}$ & $\begin{array}{l}\text { Std. Error of the Durbin-Watson } \\
\text { Estimate }\end{array}$ \\
\hline
\end{tabular}

\begin{tabular}{llllll}
1 &, $710^{\text {a }}$ &, 504 &, 462 & 5,709304 & 2,113 \\
\hline
\end{tabular}

a. Predictors: (Constant), Leverage, ESOP, TATO

b. Dependent Variable: ROA

Sumber: Output SPSS 20 (Laporan keuangan Publikasi, diolah)

Berdasarkan tabel nilai DW sudah lebih besar dari sebelumnya, yaitu sebesar 2,113. Sehingga jika dimasukkan dalam ketentuan DW maka dU $<$ DW $<4-$ dU dapat terpenuhi yaitu dengan nilai saat ini 1,659 $<2,113<2,341$ yang artinya model regresi linier yang digunakan sudah bebas dari autokorelasi, dengan kata lain model regresi ini layak dilanjutkan untuk dilakukan uji selanjutnya.

Berdasarkan hasil uji asumsi klasik yang telah dilakukan sebelumnya dapat ditarik kesimpulan bahwa model regresi yang digunakan dalam penelitian ini layak untuk dilakukan uji analisis regresi linier. Adapun pengolahan regresi linier telah dilakukan melalui beberapa tahapan guna mengetahui hubungan antara beberapa variabel independen dengan variabel dependennya.

12 Ade Aprianto dkk (2020), Metode Cochrane Ocrutt untuk Mengatasi Autokorelasi pada Estimasi Parameter Ordinary Least Squares, Bimaster Volume 09 No 1 hal 95-102. 
Tabel 5

Hasil Perhitungan Regresi Linier Berganda

\begin{tabular}{|c|c|c|c|c|c|c|c|c|}
\hline \multicolumn{9}{|c|}{ Coefficients $^{a}$} \\
\hline \multirow{2}{*}{\multicolumn{2}{|c|}{ Model }} & \multicolumn{2}{|c|}{$\begin{array}{l}\text { Unstandardized } \\
\text { Coefficients }\end{array}$} & \multirow{2}{*}{$\begin{array}{c}\text { Standardi } \\
\text { zed } \\
\text { Coefficien } \\
\text { ts } \\
\text { Beta }\end{array}$} & \multirow[t]{2}{*}{$\mathrm{t}$} & \multirow[t]{2}{*}{ Sig. } & \multicolumn{2}{|c|}{$\begin{array}{l}\text { Collinearity } \\
\text { Statistics }\end{array}$} \\
\hline & & B & $\begin{array}{l}\text { Std. } \\
\text { Error }\end{array}$ & & & & $\begin{array}{l}\text { Toler } \\
\text { ance }\end{array}$ & VIF \\
\hline \multirow[t]{4}{*}{1} & $\begin{array}{l}\text { (Cons } \\
\operatorname{tant} \text { ) }\end{array}$ & $-1,810$ & 1,089 & & 1,661 & ,106 & & \\
\hline & ESOP & $\begin{array}{r}2,872 \mathrm{E}- \\
010\end{array}$ & ,000 & ,404 & 3,321 & ,002 & ,955 & 1,047 \\
\hline & TATO & ,067 & ,017 & ,487 & 3,974 & 000 & ,943 & 1,061 \\
\hline & $\begin{array}{l}\text { Lever } \\
\text { age }\end{array}$ &, 004 & 002 & 341 & 2,813 & ,008 & ,965 & 1,037 \\
\hline
\end{tabular}

a. Dependent Variable: ROA

Sumber: Output SPSS 20 (Laporan keuangan Publikasi, diolah)

Dari hasil analisis regresi linier berganda pada tabel 5 diatas dapat dilihat bahwa koefisien variabel independen ESOP $\left(\mathrm{X}_{1}\right)$ sebesar 2,872, koefisien TATO $\left(\mathrm{X}_{2}\right)$ sebesar 0,067, koefisien leverage $\left(\mathrm{X}_{3}\right)$ sebesar 0,004 dan konstanta (a) sebesar -1,810 sehingga model persamaan regresi yang diperoleh dalam penelitian ini sebagai berikut.

$$
Y=(-1,810)+2,872 X_{1}+0,067 X_{2}+0,004 X_{3}+e
$$

\section{Koefisien Determinasi ( $\left.\mathbf{R}^{2}\right)$}

Adapun hasil pengujian menggunakan SPSS 20 menunjukkan hasil $\mathrm{R}^{2}$ seperti yang ada pada tabel berikut.

Tabel 6

koefisien Determinasi

Model Summary ${ }^{b}$

\begin{tabular}{lrrrrr}
\hline Model & $\mathrm{R}$ & $\mathrm{R}$ Square & $\begin{array}{r}\text { Adjusted R } \\
\text { Square }\end{array}$ & $\begin{array}{r}\text { Std. Error of } \\
\text { the Estimate }\end{array}$ & $\begin{array}{r}\text { Durbin- } \\
\text { Watson }\end{array}$ \\
1 &, $710^{\mathrm{a}}$ &, 504 &, 462 & 5,709304 & 2,113 \\
\hline
\end{tabular}

a. Predictors: (Constant), Leverage, ESOP, TATO

b. Dependent Variable: ROA

Sumber: Output SPSS 20 (Laporan keuangan Publikasi, diolah)

Dari hasil statistik pada tabel di atas dapat dilihat bahwa pengaruh variabel-variabel independen (ESOP,TATO dan Leverage) terhadap variabel dependen (ROA) dinyatakan dengan nilai koefisien determinasi $\left(\mathrm{R}^{2}\right)$ yakni sebesar 0,504 atau 50,4\%. Artinya 50,4\% variasi Return On Asset yang dapat dijelaskan oleh variasi dari variabel independen (Employee Stock Ownership Program, Total Asset Turnover dan Leverage) sedangkan sisanya sebesar $100 \%-50,4 \%=49,6 \%$ dijelaskan oleh sebab-sebab lain dari luar model maupun variabel lain yang tidak di teliti dalam penelitian kali ini. 


\section{Uji T (Parsial)}

Terdapat dua cara yang digunakan dalam uji T pada penelitian kali ini. Yang pertama dengan membandingkan nilai $\alpha$ dengan nilai Sig, dimana $\alpha=0,05$ atau 5\% dengan ketentuan apabila Sig $<0,05$ maka variabel independen ada pengaruhnya terhadap variabel dependen. yang kedua yaitu menggunakan distribusi $t$ dengan membandingkan $t$ tabel dan $t$ hitungnya, dengan ketentuan apabila $t$ hitung $>t$ tabel maka variabel independen ada pengaruhnya terhadap variabel dependen dan sebaliknya.

Dalam uji T pada SPSS 20 maka dihasilkan output sebagai berikut:

Tabel 7

Hasil Analisis Uji T

Coefficients ${ }^{\mathrm{a}}$

\begin{tabular}{|c|c|c|c|c|c|c|c|c|}
\hline \multirow[t]{3}{*}{ Model } & \multirow[b]{3}{*}{$\begin{array}{l}\text { (Consta } \\
\text { nt) }\end{array}$} & \multicolumn{2}{|c|}{$\begin{array}{l}\text { Unstandardized } \\
\text { Coefficients }\end{array}$} & \multirow{3}{*}{$\begin{array}{c}\text { Standardiz } \\
\text { ed } \\
\text { Coefficient } \\
\text { s } \\
\text { Beta }\end{array}$} & \multirow{3}{*}{$\begin{array}{c}\mathrm{t} \\
-1,661\end{array}$} & \multirow{3}{*}{$\begin{array}{l}\text { Sig. } \\
\text {,106 }\end{array}$} & \multicolumn{2}{|c|}{$\begin{array}{c}\text { Collinearity } \\
\text { Statistics }\end{array}$} \\
\hline & & B & Std. Error & & & & $\begin{array}{l}\text { Toleran } \\
\text { ce }\end{array}$ & VIF \\
\hline & & $-1,810$ & 1,089 & & & & & \\
\hline \multirow[t]{3}{*}{1} & ESOP & $\begin{array}{r}2,872 \mathrm{E}- \\
010\end{array}$ & ,000 & ,404 & 3,321 & ,002 & 955 & 1,047 \\
\hline & TATO & ,067 & ,017 & 487 & 3,974 & ,000 & 943 & 1,061 \\
\hline & $\begin{array}{l}\text { Leverag } \\
\mathrm{e}\end{array}$ & ,004, & ,002 & ,341 & 2,813 & ,008 & ,965 & 1,037 \\
\hline
\end{tabular}

a. Dependent Variable: ROA

Sumber: Output SPSS 20 (Laporan keuangan Publikasi, diolah)

Dari tabel di atas dapat diketahui hasil uji t jika menggunakan perbandingan antara nilai $\alpha$ dengan nilai Sig maka diperoleh hasil sebagai berikut:

a. ESOP ; nilai Sig $=0,002$, maka $0,002<0,05$ yang artinya variabel ESOP $\left(\mathrm{X}_{1}\right)$ ada pengaruhnya terhadap variabel ROA (Y)

b. TATO ; nilai Sig $=0,000$. maka $0,000<0,05$ yang artinya variabel TATO $\left(\mathrm{X}_{2}\right)$ ada pengaruhnya terhadap variabel ROA (Y)

c. Leverage ; nilai Sig = 0,008, maka 0,008 $<0,05$ yang artinya variabel Leverage $\left(\mathrm{X}_{3}\right)$ ada pengaruhnya terhadap variabel ROA (Y)

Namun uji $\mathrm{T}$ juga bisa di nilai menggunakan distribusi t dengan membandingkan $\mathrm{t}$ tabel dan $\mathrm{t}$ hitungnya,dimana sebelum membandingkan penulis perlu mengetahui nilai $\mathrm{t}$ tabelnya dengan menghitung menggunakan rumus t tabel $=(\alpha / 2, n-k-1)$. Dimana t tabel $=($ $0,05 / 2,39-3-1)$ maka $t$ tabel $=(0,025 ; 35)$, atau $t$ tabel $=2,030$. Dari tabel 4.11 di atas dapat dihitung berdasarkan distribusi t bahwa:

a. ESOP ; $t$ hitung $>t$ tabel yaitu 3,908 $>2,030$ yang artinya variabel ESOP $\left(\mathrm{X}_{1}\right)$ ada pengaruh positif terhadap variabel ROA (Y) sehingga $\mathrm{H}_{0}$ ditolak dan $\mathrm{H}_{2}$ dapat diterima.

b. TATO ; t hitung $>$ t tabel yaitu 3,321 > 2,030 yang artinya variabel TATO $\left(\mathrm{X}_{2}\right)$ ada pengaruh positif terhadap variabel $\mathrm{ROA}(\mathrm{Y})$ sehingga $\mathrm{H}_{0}$ ditolak dan $\mathrm{H}_{3}$ dapat diterima.

c. Leverage ; t hitung $>t$ tabel yaitu 2,813 > 2,030 yang artinya variabel Leverage $\left(\mathrm{X}_{3}\right)$ ada pengaruh positif terhadap variabel ROA (Y) sehingga $\mathrm{H}_{0}$ ditolak dan $\mathrm{H}_{4}$ dapat diterima. 


\section{Uji F (Simultan)}

Hasil Uji F dapat dilakukan dengan beberapa cara sama seperti pada uji parsial, yaitu yang pertama dengan membandingkan nilai $\alpha$ dengan nilai Sig, dimana $\alpha=$ 0,05 atau 5\% dengan ketentuan apabila Sig < 0,05 maka variabel-variabel independen ( Employee Stock Ownership Program, Total Asset Turnover dan Leverage ) ada pengaruhnya terhadap variabel dependen (Return On Asset). yang kedua yaitu menggunakan distribusi $\mathrm{F}$ dengan membandingkan $\mathrm{F}$ tabel dan $\mathrm{F}$ hitungnya, dengan ketentuan apabila $\mathrm{F}$ hitung $>\mathrm{F}$ tabel maka variabel-variabel independen ada pengaruh yang signifikan terhadap variabel dependen dan sebaliknya.

Hasil uji $\mathrm{F}$ yang dilakukan dengan menggunakan SPSS 20 dapat di lihat dengan menggunakan tabel berikut.

Tabel 8

Hasil Analisis Uji F

\begin{tabular}{llrrrrr}
\multicolumn{8}{c}{ Hasil Analisis Uji F } \\
ANOVA \\
Model & & Sum of & df & Mean Square & F & Sig. \\
& Squares & & & & &, $000^{\text {b }}$ \\
& Regression & 1160,547 & 3 & 386,849 & 11,868 & \\
\hline & Residual & 1140,865 & 35 & 32,596 & & \\
& Total & 2301,413 & 38 & & & \\
\hline
\end{tabular}

a. Dependent Variable: ROA

b. Predictors: (Constant), Leverage, ESOP, TATO

Sumber: Output SPSS 20 (Laporan keuangan Publikasi, diolah)

Dari tabel di atas dapat dilihat jika menggunakan perbandingan nilai $\alpha$ dengan nilai Sig maka Sig < 0,05 yaitu 0,000 < 0,05 yang artinya Employee Stock Ownership Program $\left(\mathrm{X}_{1}\right)$, Total Asset Turnover $\left(\mathrm{X}_{2}\right)$ dan Leverage $\left(\mathrm{X}_{3}\right)$ secara bersama-sama ada pengaruh yang signifikan terhadap Return On Asset (Y).

Sedangkan jika menggunakan distribusi $\mathrm{F}$ dengan membandingkan $\mathrm{F}$ tabel dan $\mathrm{F}$ hitungnya. Dimana sebelum membandingkan penulis perlu mengetahui nilai $\mathrm{F}$ tabelnya dengan menghitung menggunakan rumus $\mathrm{F}$ tabel $=(\mathrm{k} ; \mathrm{n}-\mathrm{k})$ atau $(3 ; 39-3)$ hasilnya adalah $\mathrm{F}$ tabel $=(3 ; 36)$ yang artinya $\mathrm{F}$ tabel $=2,87$.

Sekarang bandingkan antara $\mathrm{F}$ hitung dengan $\mathrm{F}$ tabelnya, berdasarkan tabel nilai $\mathrm{F}$ hitung $=11,868$ maka F hitung $>\mathrm{F}$ tabel yaitu senilai 11,868 $>2,87$ yang artinya Employee Stock Ownership Program $\left(\mathrm{X}_{1}\right)$, Total Asset Turnover $\left(\mathrm{X}_{2}\right)$ dan Leverage $\left(\mathrm{X}_{3}\right)$ secara bersamasama ada pengaruh yang signifikan terhadap Return On Asset $(\mathrm{Y})$, sehingga $\mathrm{H}_{0}$ ditolak dan $\mathrm{H}_{1}$ diterima.

\section{PENUTUP}

Berdasarkan hasil pembahasan, analisis data, pengjuian hipotesis tentang "Pengaruh Employee Stock Ownership Program, Total Asset Turnover dan Leverage Terhadap Return On Asset pada Perusahaan Yang Terdaftar Pada Bursa Efek Indonesia". Maka dapat ditarik kesimpulan sebagai berikut:

1. Hasil penelitian ini berbanding lurus dengan uji Fnya, dimana dalam penelitian kali ini nilai signya sebesar 0,000 artinya $0,000<0,05$ dan nilai $\mathrm{F}$ hitung $>\mathrm{F}$ tabelnya yaitu $11,868>2,87$ dengan demikian dapat di tarik kesimpulan bahwa $\mathrm{H}_{0}$ di tolak dan $\mathrm{H}_{1}$ 
diterima, yang menunjukkan bahwa Employee Stock Ownership Program, Total Asset Turnover dan Leverage memiliki pengaruh yang signifikan terhadap Return On Asset.

2. Hasil penelitian yang dilakukan berdasarkan pengujian hipotesis dengan uji T, dimana nilai sig variabel ESOP sebesar 0,002 artinya 0,002 <0,05, dan nilai t hitung pada ESOP $>\mathrm{t}$ tabelnya, yaitu 3,321 > 2,030 sehingga dapat di tarik kesimpulan bahwa $\mathrm{H}_{0}$ di tolak dan $\mathrm{H}_{2}$ diterima yang artinya Employee Stock Ownership Program: memiliki pengaruh yang signifikan terhadap Return On Asset pada perusahaan yang terdaftar di BEI.

3. Selanjutnya hasil uji hipotesis pada variabel Total Asset Turnover pada uji $\mathrm{T}$ menunjukkan hasil dimana nilai sig variabel TATO adalah 0,000 artinya 0,000 $<0,05$ dan nilai $\mathrm{t}$ hitung pada TATO $>\mathrm{t}$ tabelnya yakni 3,974 $>2,030$ sehingga dapat di tarik kesimpulan bahwa $\mathrm{H}_{0}$ di tolak dan $\mathrm{H}_{3}$ diterima yang artinya Total Asset Turnover: memiliki pengaruh yang signifikan terhadap Return On Asset pada perusahaan yang terdaftar di BEI.

4. Hasil uji hipotesis pada variabel Leverage pada uji T menunjukkan hasil dimana nilai sig variabel TATO adalah 0,008 artinya 0,008 $<0,05$ dan nilai t hitung pada TATO $>\mathrm{t}$ tabelnya yakni 2,813 > 2,030 sehingga dapat di tarik kesimpulan bahwa $\mathrm{H}_{0}$ di tolak dan $\mathrm{H}_{4}$ diterima yang artinya Leverage: memiliki pengaruh yang signifikan terhadap Return On Asset pada perusahaan yang terdaftar di BEI.

\section{DAFTAR PUSTAKA}

Endah Dewi Purnamasari. Analisis Pengaruh Laverage terhadap Profitabilitas Perusahaan yang Termasuk LQ45 Periode Agustus 2015- Januari 2016 di Bursa efek Indonesia. Jurnal Ilmiah Ekonomi Global Masa Kini Vol 8 No 01 ISSN PRINT : 2089-6018, 2019.

Herdinata C. Reaksi Pasar Terhadap Pengumuman Employee Stock Ownership Program. Jurnal Keuangan dan Perbankan. Vol.16, hlm.77-85, 2012.

M Firza A dan Ade Gunawan. Pengaruh Current Ratio dan Total Assets Turnover Terhadap Return On Assets pada Perusahaan Plastik dan Kemasan. Jurnal Riset Akuntansi Vol. 17, No. 2, 2018.

Muhamad Yusril Arsyad. Analisis Penerapan Employee Stock Ownership Program Terhadap Kinerja Perusahaan yang Terdaftar di Bursa Efek Indonesia. Dspace Universitas Islam Indonesia No.14, 2018.

Nur Afni Yunita. Pengaruh Employee Stock Ownership Program (ESOP) Terhadap Profitabilitas Perusahaan Yang terdaftar di Bursa Efek Indonesia. Jurnal Visioner \& Strategis.Volume 7, Nomor 1,Maret 2018 ISSN: 2338-2864 p. 23-30.

Nur Anita Chandra Putry dan Teguh Erawati. Pengaruh Current Ratio, Total Assets Turnover dan Net Profit Margin Terhadap Return On Assets. Jurnal Akuntansi Vol 1 No 2 Desember 2013, hlm.23.

Yulita M. Gunde dkk. Analisis pengaruh leverage terhadap profitabilitas pada perusahaan manufaktur sub industri food and baverages yang terdaftar di BEI(periode 2012-2015). Jurnal EMBA Vol.5 No.3 September 2017, Hal.4185-4194 ISSN 2303-1174.

Ria Ans Kurniati dan Muhammad Saifi. Pengaruh Employee Stock Ownership Program dan Leverage terhadap kinerja keuangan (Studi pada Perusahaan Sektor Perbankan yang Terdaftar Di Bursa Efek Indonesia Tahun 2014-2016). Jurnal Administrasi Bisnis Vol. 62 No. 2 September 2018 administrasibisnis.studentjournal.ub.ac.id.hlm.151. 